\title{
THE NORMAL LEVELS OF 17-HYDROXYCORTICOSTEROIDS IN THE PERIPHERAL BLOOD OF MAN ${ }^{1}$
}

\author{
By EUGENE L. BLISS, AVERY A. SANDBERG, ${ }^{2}$ DON H. NELSON, ${ }^{3}$ AND \\ KRIS EIK-NES 4 \\ (From the Departments of Psychiatry, Biological Chemistry, and Medicine, University of Utah \\ College of Medicine, Salt Lake City, Utah)
}

(Submitted for publication April 21, 1953; accepted May 15, 1953)

Research in the field of adrenal cortical function has been limited by the inability of existing techniques to measure precisely the kind and amounts of steroids elaborated by the gland. Particularly in man, the indicators have been indirect and inadequate. These have consisted principally of the alterations in certain non-steroid constituents of the blood, changes in the total number of circulating lymphocytes and eosinophils, and variations in end products of steroid metabolism found in the urine.

Biological assays $(1,2)$ of the blood level of adrenal cortical hormones were developed with the hope that they would provide greater specificity, but have proved to be neither sufficiently sensitive nor precise. Chemical methods $(3,4$, 5 ) for the determination of blood steroids have been proposed.

The first satisfactory direct quantitative measurement of 17-hydroxycorticosteroids in the blood of human subjects was reported by Nelson and Samuels (6). This would include such "17-OH" compounds as E, F, and S, when present. Actually,

\footnotetext{
1 This investigation was supported in part by research grants A-29 from the National Institute of Arthritis and Metabolic Diseases and M-451 from the National Institute of Mental Health, of the National Institutes of Health, Public Health Service, in part by the Medical Research and Development Board, Office of the Surgeon General, Department of the Army, under Contract No. DA-49-007-MD-136, in part under a research grant from the American Cancer Society and in part by the Scottish Rite Foundation.

2 Postdoctorate Research Fellow of the National Institutes of Health, 1951-52. Fellow of the Dazian Foundation for Medical Research, 1952-53.

3 Present address: Lt. J. G., Naval Medical School, U. S. Naval Medical Center, Bethesda 14, Md.

4 Postdoctoral Fulbright Travel Fellow and Baxter Research Fellow.
}

the major component in the peripheral blood of man appears to be 17-hydroxycorticosterone (compound $F)(6,7,8,9)$. Since this seems to be the principal 17-hydroxycorticosteroid secreted by the normal adrenal gland (9), the method offers an excellent direct measure of adrenal cortical activity.

This report is concerned with the concentration of circulating 17-hydroxycorticosteroids in the peripheral venous blood of normal adults, the range of normal values, diurnal variations, and the degree of fluctuation in blood levels of cortical steroids for any one individual from day to day and week to week.

\section{MATERIALS AND METHODS}

The levels of 17-hydroxycorticosteroids in plasma were determined by the method of Nelson and Samuels (6). A few samples were run by both this method and that of Sweat and Farrell (10). Subjects were medical students, residents, graduate students and hospital personnel having no known diseases. The only exceptions to this were the aged patients, none of whom were acutely ill, although the majority suffered from the usual degenerative changes of old age.

Blood samples were obtained by venipuncture and placed in tubes containing $4 \mathrm{mg}$. of heparin. These were then centrifuged, the plasma removed and the samples refrigerated. All specimens, save for the diurnal ones, were drawn between 8 and 8:30 A.M. on fasting subjects. In the case of diurnal studies, some subjects were studied while fasting; others were permitted to eat. These will be designated.

\section{RESULTS}

\section{Comparison of analytical methods}

The results on duplicate samples analyzed by the technique of Nelson and Samuels, and that of Sweat and Farrell are given in Table I. It is evident that the two procedures measure the same compounds, since the values are almost identical. 
TABLE I

Comparison of analytic methods

\begin{tabular}{|c|c|c|}
\hline Subject & $\begin{array}{l}\text { Nelson and Samuels } \\
\text { Technique } \\
\text { 17-OH Corticosteroids } \\
\text { Mg./100 ml. plasma }\end{array}$ & $\begin{array}{c}\text { Sweat and Farrell } \\
\text { Technique } \\
\text { 17-OH Corticosterone } \\
\mu g . / 100 \text { ml. plasmá }\end{array}$ \\
\hline B & 30 & 28 \\
\hline L & 11 & 13 \\
\hline \multirow[t]{3}{*}{$\mathbf{C}$} & 11 & 10 \\
\hline & $20^{*}$ & $20^{*}$ \\
\hline & $35^{*}$ & $31^{*}$ \\
\hline D & 16 & 16 \\
\hline Ad & $25^{*}$ & $31^{*}$ \\
\hline A & $27^{*}$ & $27^{*}$ \\
\hline 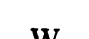 & $30^{*}$ & $30^{*}$ \\
\hline W & $20^{*}$ & $25^{*}$ \\
\hline
\end{tabular}

* Levels after ACTH administration.

\section{Normal values-Young healthy adults}

Two hundred and sixty-seven determinations were made on 120 adults, 91 of whom were male and 29 female. The age range was 20 to 45 . In Figure 1, the distribution of normal values is charted. Since the distribution of normal values was skewed, standard statistical techniques were not applicable. The curve was transformed into a normal distribution, therefore, by converting all values to the $2 / 3$ power $(\times 2 / 3)$. The means, standard deviations, standard errors of the means and 95 per cent range were then calculated by routine methods. These values were then reconverted to give actual concentrations.

As indicated in Table II, the mean of the group is $13 \mu \mathrm{g}$. per $100 \mathrm{ml}$. plasma with a standard deviation of $\pm 6 \mu \mathrm{g}$. Values ranged from less than $2 \mu \mathrm{g}$. to $34 \mu \mathrm{g}$. per $100 \mathrm{ml}$. plasma. Since each value represents a single measurement, and as no results were excluded, the data must include analytical errors, as well as human variation. In view of this, it is reasonable to accept the 95 per cent range, $3-26 \mu \mathrm{g}$. per $100 \mathrm{ml}$. of plasma, as representing the normal distribution. It should be emphasized that these are fasting values and reflect steroid levels between 8 and 8:30 A.M.
NORMAL VALUES 17-OH CORTICOSTEROIOS $\mu \mathrm{g} / 100 \mathrm{ml}$ PLASMA

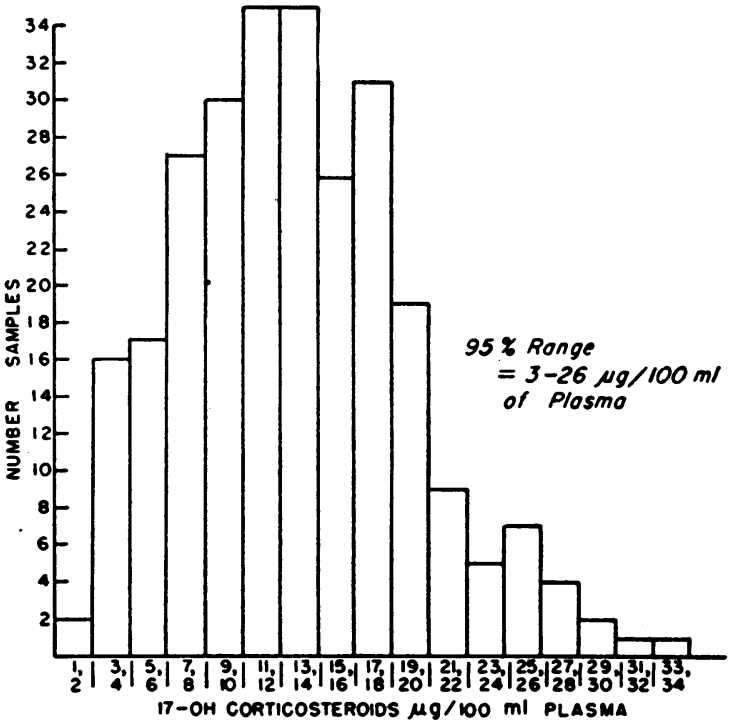

Figure 1

The mean value for females was $15 \pm 6 \mu \mathrm{g}$. per $100 \mathrm{ml}$. plasma compared to $12 \pm 6 \mu \mathrm{g}$. per 100 ml. plasma for males. A sex difference, if any exists, must be small.

\section{Normal values-Aged population}

A group of 29 elderly patients, 27 males and 2 females, whose average age was 78 years, was also studied. The mean steroid level for the group was $12 \pm 6 \mu \mathrm{g}$. per $100 \mathrm{ml}$. plasma (Table II).

\section{Range of variation in the same individual}

Twenty-one subjects were studied repeatedly over a period of several months. Blood samples were drawn at intervals varying from several days to several weeks. There was considerable variation in steroid levels from day to day and week to week in most individuals (Table III). Examples are: Subject L., $6 \mu \mathrm{g}$. to $18 \mu \mathrm{g}$.; Subject

TABLE II

Normal values-17-hydroxycorticosteroids $\mu g$. per $100 \mathrm{ml}$. plasma

\begin{tabular}{lcccccc}
\hline \hline Groups & $\begin{array}{c}\text { No. of } \\
\text { subjects }\end{array}$ & $\begin{array}{c}\text { No. of } \\
\text { studies }\end{array}$ & Age & $\begin{array}{c}\text { Mean and } \\
\text { S.D. }\end{array}$ & Range & $\begin{array}{c}\text { Mean and } \\
\text { S.E. }\end{array}$ \\
\hline Young adults & 120 & 267 & $20-45$ & $13 \pm 6 \mu g$. & 2 to $34 \mu \mathrm{g}$. & $13 \pm 0.4$ \\
Males & 91 & 195 & $20-45$ & $12 \pm 6 \mu \mathrm{g}$. & 2 to $34 \mu \mathrm{g}$. & $12 \pm 0.4$ \\
Females & 29 & 72 & $20-45$ & $15 \pm 6 \mu \mathrm{g}$. & 2 to $31 \mu \mathrm{g}$. & $15 \pm 0.7$ \\
Aged & 29 & 29 & $64-95$ & $12 \pm 6 \mu \mathrm{g}$. & 3 to $24 \mu \mathrm{g}$.
\end{tabular}


TABLE III

Range of variation in same individual

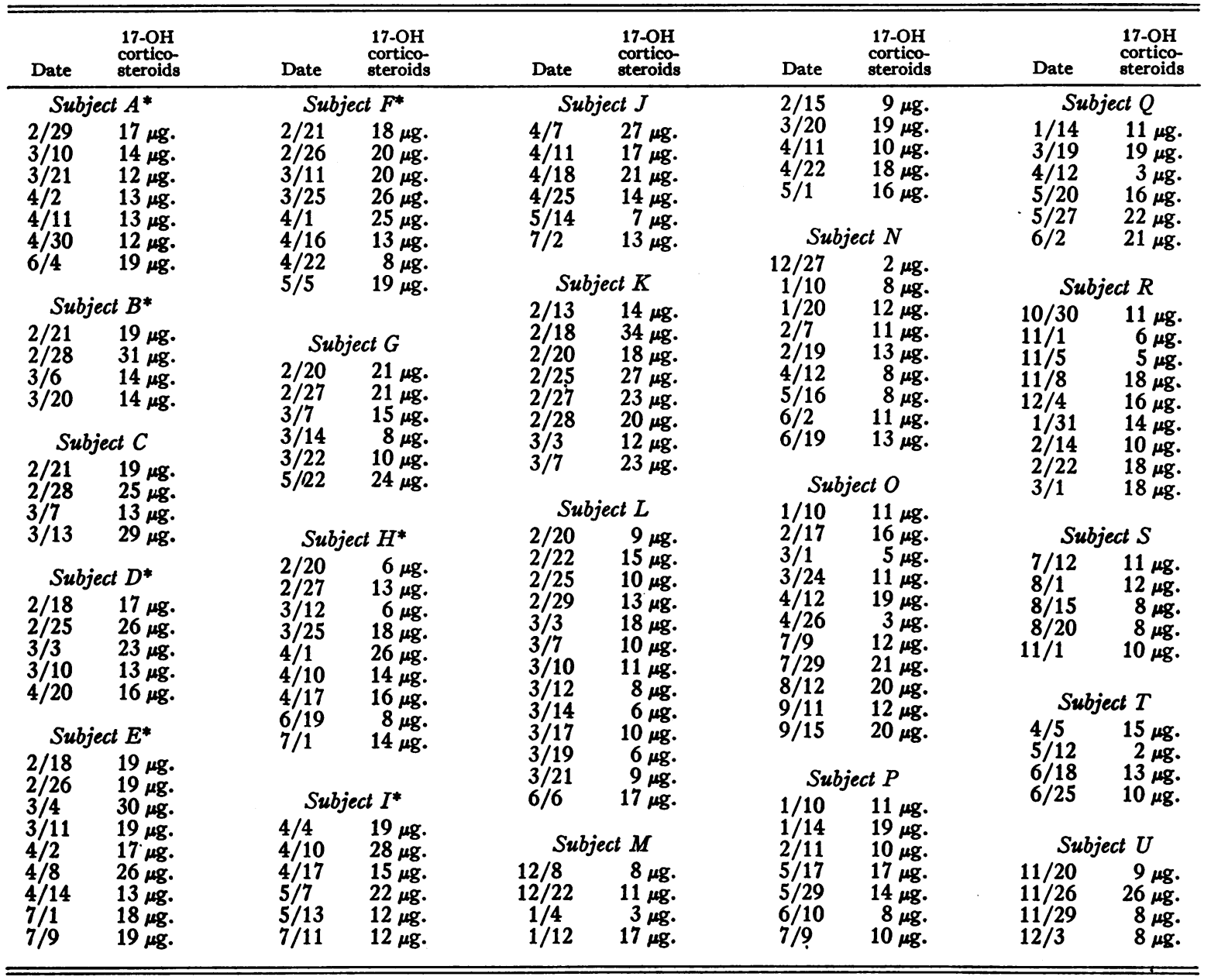

* Female; all other subjects male.

K., $12 \mu \mathrm{g}$. to $34 \mu \mathrm{g}$.; Subject H., $6 \mu \mathrm{g}$. to $26 \mu \mathrm{g}$., and Subject N., $3 \mu \mathrm{g}$. to $21 \mu \mathrm{g}$. per $100 \mathrm{ml}$. plasma.

\section{Diurnal variations}

These data are listed in Table IV. Observations on the fasting and non-fasting subjects were pooled since the mean values on those who ate breakfasts and those who did not were almost identical.

Although there were a number of individual exceptions, in general the tendency was for the highest levels to occur in the early morning. Between 8 A.M. and 12 noon the level tends to drop. As the day advances, steroid levels fluctuate considerably, but continue to remain on this lower plateau (Figure 2).

\section{DISCUSSION}

In the normal, healthy, fasting adult, the mean plasma level of 17-hydroxycorticosteroids was $13 \pm 6 \mu \mathrm{g}$. per $100 \mathrm{ml}$. between 8 and 8:30 A.M. Values for males and females were not significantly different. Since almost identical values were found in the 26 elderly subjects whose average age was 78 , it seems likely that adults maintain virtually the same range of peripheral blood adrenal steroid levels over the span of their mature years.

For any one individual, values were found scattered throughout the normal range when studies at 8 A.M. were repeated at daily, weekly, or monthly intervals. This range is much wider than that of most chemical constituents of the 
DIURNAL VARIATIONS IN 17 HYDROXYCORTICOSTEROIDS

$\mu 9 / 100 \mathrm{ml}$ PLASMA

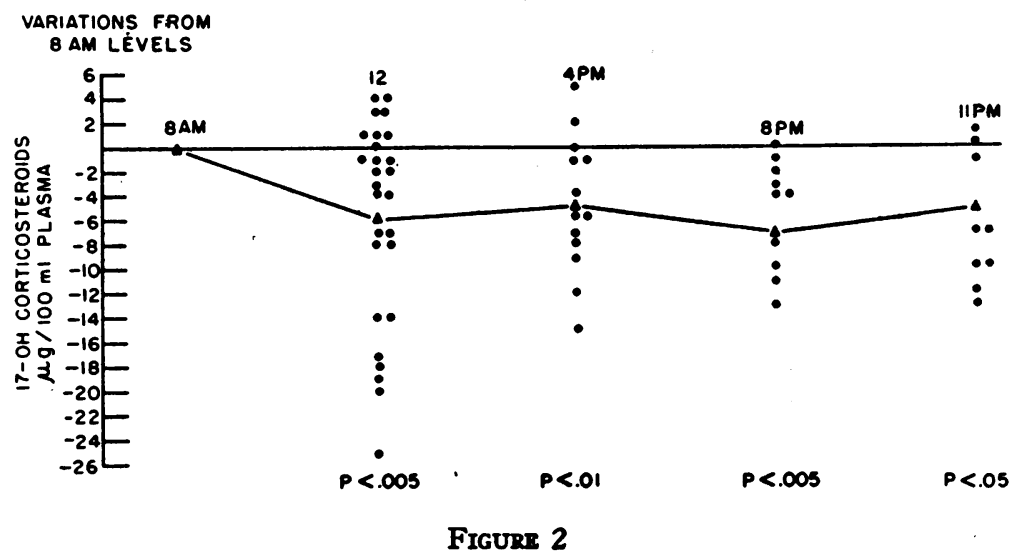

TABLE IV

Data-diurnal variations in 17-hydroxycorticosteroids

\begin{tabular}{|c|c|c|c|c|c|c|c|c|c|c|c|c|c|c|c|c|c|}
\hline Subjects & A.M. & 9 & 10 & 11 & $\begin{array}{c}12 \\
\text { Noon }\end{array}$ & P.M. & 2 & 3 & 4 & 5 & 6 & 7 & 8 & 9 & 10 & 11 & $\begin{array}{l}12 \\
\text { Midnight }\end{array}$ \\
\hline $\begin{array}{l}\text { No. } 1 \\
\text { No. } 2 \\
\text { No. } 3 \\
\text { No. } 4 \\
\text { No. } 5 \\
\text { No. } 6 \\
\text { No. } 7 \\
\text { No. } 8 \\
\text { No. } 9 \\
\text { No. } 10 \\
\text { No. } 11 \\
\text { No. } 12 \\
\text { No. } 13 \\
\text { No. } 14 \\
\text { No. } 15 \\
\text { No. } 16 \\
\text { No. } 17 \\
\text { No. } 18 \\
\text { No. } 19^{*} \\
\text { No. } 20^{*} \\
\text { No. } 21^{*} \\
\text { No. } 22^{*} \\
\text { No. } 23^{*} \\
\text { No. } 24^{*} \\
\text { No. } 25^{*} \\
\text { No. } 26^{*} \\
\text { No. } 27^{*} \\
\text { No. } 28^{*} \\
\text { No. } 29^{*} \\
\text { No. } 30^{*} \\
\text { No. } 31^{*} \\
\text { No. } 32^{*} \\
\text { No. } 33^{*} \\
\text { No. } 34^{*} \\
\text { No. } 35^{*} \\
\text { No. } 36^{*} \\
\text { No. } 37^{*}\end{array}$ & $\begin{array}{r}16 \\
16 \\
14 \\
12 \\
19 \\
9 \\
23 \\
12 \\
8 \\
7 \\
15 \\
10 \\
15 \\
9 \\
8 \\
11 \\
11 \\
13 \\
27 \\
20 \\
26 \\
14 \\
25 \\
30 \\
26 \\
23 \\
29 \\
31 \\
13 \\
11 \\
8 \\
9 \\
8 \\
17 \\
11 \\
27 \\
16\end{array}$ & $\begin{array}{r}14 \\
22 \\
25 \\
12 \\
21 \\
21 \\
17 \\
22 \\
20 \\
20 \\
6\end{array}$ & $\begin{array}{r}9 \\
14 \\
20 \\
20 \\
17 \\
8 \\
11 \\
12 \\
18 \\
10 \\
6\end{array}$ & $\begin{array}{r}11 \\
13 \\
10 \\
6\end{array}$ & $\begin{array}{r}8 \\
6 \\
23 \\
18 \\
17 \\
\\
8 \\
22 \\
15 \\
6 \\
12 \\
12 \\
6 \\
7 \\
7 \\
10 \\
14 \\
10 \\
12\end{array}$ & $\begin{array}{r}7 \\
7 \\
6 \\
11\end{array}$ & $\begin{array}{l}8 \\
5\end{array}$ & & $\begin{array}{r}2 \\
7 \\
11 \\
5 \\
8 \\
13 \\
10 \\
14 \\
4 \\
6 \\
9 \\
13 \\
10 \\
5 \\
6\end{array}$ & $\begin{array}{l}15 \\
16 \\
\\
8\end{array}$ & & & $\begin{array}{l}\cdot \\
8 \\
6 \\
2 \\
7 \\
5 \\
7 \\
3 \\
2\end{array}$ & & 16 & $\begin{array}{r} \\
3 \\
9 \\
2 \\
2 \\
9 \\
18 \\
4 \\
3\end{array}$ & 4 \\
\hline
\end{tabular}

* Fasting-no breakfast. 
circulating fluids under normal conditions, and argues against a simple homeostatic concept. It must be recognized, however, that the extraction procedures may remove steroid which is loosely bound as well as that which is free. Until this problem is answered, it is impossible to draw conclusions regarding the constancy of the free 17 hydroxycorticosteroid levels.

While the spread in normal individuals may be wide, disturbances of the adrenal cortex which can be diagnosed clinically usually give values outside this range. In most Addisonians there is no circulating 17-hydroxycorticosteroids in the peripheral blood; although a few who presumably have remnants of intact tissue show low levels (11). Patients with Cushing's disease have pathologically elevated titres $(9,11)$.

Diurnal studies demonstrated certain trends, although there were many individual exceptions. The most constant finding was the presence of maximal 17-hydroxycorticosteroid levels in the early morning. Only rarely were later samples higher, and then only by small amounts. Whether this high level early in the morning represents an accumulation of steroids during sleep, a greater need and increased steroid production in the early morning hours, or an increase in steroid production with a decrease in peripheral utilization it is difficult to say. In any event, most of our subjects demonstrated a decline in 17-hydroxycorticosteroid levels during the day. Late evening levels remained low. This is consistent with the data of Pincus, Hoagland, Romanoff, and Carlo (12, 13), who found comparable changes in the diurnal excretion of $17-$ ketosteroids and neutral reducing lipids in the urine, as well as those of Sandberg and his co-workers (14), who observed the same pattern in the urinary 17-hydroxycorticosteroids following glucuronidase hydrolysis. Both groups recorded the highest urinary levels in the morning.

\section{SUMMARY}

1. Plasma levels of 17-hydroxycorticosteroids were determined in normal adult subjects by the method of Nelson and Samuels.

2. The mean 17-hydroxycorticosteroid level in young adults was $13 \pm 6 \mu \mathrm{g}$; $15 \pm 6 \mu \mathrm{g}$. for females and $13 \pm 6 \mu \mathrm{g}$. for males. The 95 per cent range for the group was 3-26 $\mu \mathrm{g}$. per $100 \mathrm{ml}$. of plasma.

3. In a group of elderly subjects whose mean age was 78 years, the average level was $12 \pm$ $6 \mu \mathrm{g}$.

4. Diurnal studies revealed high 17-hydroxycorticosteroid levels in the early morning. These tended to drop to a lower plateau over the course of the day and evening, although considerable individual variation was evident.

5. The wide range of normal 17-hydroxycorticosteroid values suggests an adrenal cortical homeostatic balance in man which is less sensitive than that for most chemical constituents in the body fluids.

\section{ACKNOWLEDGMENTS}

The authors are indebted to Rosalind Walton, Carma Darley, and Beth Dowding for technical assistance.

\section{REFERENCES}

1. Paschkis, K. E., Cantarow, A., Walkling, A. A., and Boyle, D., Adrenal cortical hormone level in adrenal vein and peripheral blood. Endocrinology, 1950, 47, 338.

2. Vogt, M., The output of cortical hormone by the mammalian suprarenal. J. Physiol., 1943, 102, 341.

3. Corcoran, A. C., and Page, I. H., Methods for the chemical determination of corticosteroids in urine and plasma. J. Lab. \& Clin. Med., 1948, 33, 1326.

4. Hemphill, R. E., and Reiss, M., Regulation of endogenous cortin production. Endocrinology, 1947, 41, 17.

5. Wick, A. N., Hillyard, L., and MacKay, E. M., A method for measuring and the effect of adrenocorticotropic hormone on lipid-soluble reducing substances of rabbit plasma. Endocrinology, 1951, 48, 137.

6. Nelson, D. H., and Samuels, L. T., A method for the determination of 17-hydroxycorticosteroids in blood: 17-hydroxycorticosterone in the peripheral circulation. J. Clin. Endocrinol. \& Metab., 1952, $12,519$.

7. Nelson, D. H., Samuels, L. T., Willardson, D. G., and Tyler, F. H., The levels of 17-hydroxycorticosteroids in peripheral blood of human subjects. J. Clin. Endocrinol., 1951, 11, 1021.

8. Bush, I. E., Paper-chromatographic study of the secretion of the adrenal cortex in various mammalian species. J. Physiol., 1951, 115, 12.

9. Sweat, M. L., Abbott, W. E., Jeffries, W. M., and Bliss, E. L., Adrenocortical steroids in human peripheral and adrenal venous blood as determined by fluorescence. Federation Proc., 1953, 12, 141.

10. Sweat, M. L., and Farrell, G. L., Resolution and 
quantitative analysis of steroids in adrenal-vein blood. J. Clin. Endocrinol. \& Metab., 1952, 12, 968.

11. Nelson, D. H., Determination of adrenal cortical steroids in blood. Adrenal Cortex. Josiah Macy, Jr. Foundation, 1952, p. 89.

12. Pincus, G., and Hoagland, H., Steroid excretion and the stress of flying. J. Aviation Med., 1943, 14, 173.
13. Pincus, G., Romanoff, L. P., and Carlo, J., A diurnal rhythm in the excretion of neutral reducing lipids by man and its relation to the 17-ketosteroid rhythm. J. Clin. Endocrinol, 1948, 8, 221.

14. Sandberg, A. A., Nelson, D. H., Glenn, E. M., Tyler, F. H., and Samuels, L. T., 17-hydroxycorticosteroids and 17-ketosteroids in urine of human subjects: clinical application of a method employing $\beta$ glucuronidase hydrolysis. In press. 